\title{
Enantiomeric Determination of Carvedilol by a Newly Developed and Validated Chiral HPLC Method
}

\author{
Asma Rahman ${ }^{1,2}$, Mohammad Rashedul Haque ${ }^{2}$, Md. Zakir Sultan ${ }^{1}$, \\ M. Muhibur Rahman ${ }^{3}$ and Mohammad A. Rashid ${ }^{2}$ \\ ${ }^{1}$ Centre for Advanced Research in Sciences (CARS), University of Dhaka, Dhaka-1000, Bangladesh \\ ${ }^{2}$ Department of Pharmaceutical Chemistry, Faculty of Pharmacy, University of Dhaka, Dhaka-1000, Bangladesh \\ ${ }^{3}$ Department of Chemistry, University of Dhaka, Dhaka 1000, Bangladesh
}

(Received: May 29, 2018; Accepted: March 03, 2019; Published (Web): April 01, 2019)

\begin{abstract}
A new simple, selective, linear and accurate chiral HPLC method for assay of carvedilol enantiomers was developed with immobilized cellulose chiral stationary phases under normal-phase mode using hexane: isopropyl alcohol: diethyl amine: acetic acid (40: 60: 0.7: 0.3, v/v) as the mobile phase at a flow rate of $1.0 \mathrm{~mL} / \mathrm{min}$ and detection at $220 \mathrm{~nm}$. The method was validated for linearity, precision, accuracy, ruggedness, robustness and stability as per the guidelines of USP and ICH. The regression coefficients $\left(\mathrm{r}^{2}\right)$ of the linearity were found to be 0.999 for both $S$ - and $R$ - carvedilol, detection limit (LOD) were 1.67 and $1.78 \mu \mathrm{g} / \mathrm{mL}$ and quantitation limit were also found to be 5.06 and $5.41 \mu \mathrm{g} / \mathrm{mL}$ for $S$ - and $R$ - carvedilol, respectively. The average percentage of recovery was found to be $99.59 \%$ to $100.83 \%$ for $S$ - and $98.42 \%$ to $100.18 \%$ for $R$ - carvedilol, respectively. The new method can be used for enantiomeric separation and estimation of carvedilol in pharmaceutical dosage forms without any interference.
\end{abstract}

Key words: Carvedilol, method development, validation, content of enantiomers, enantiomeric purity.

\section{INTRODUCTION}

Chemically, carvedilol is $(( \pm)-1-($ carbazol-4yloxy)-3-[[2-(O-methoxy- phenoxy)ethyl]amino]-2propanol) (Figure 1). It is administered as a enatiomeric mixture of the $R(+)$ - and $S(-)$-isomers. These isomers possess vasodilation and $\beta$-blockage properties. ${ }^{1}$ It is seen that only the $S$-enantiomer of carvedilol exerts $\beta$-blocking effects.

There are many methods for the enantioselective analysis of carvedilol which include derivatization with chiral reagents (indirect methods) or the use of chiral stationary phases (direct methods).

In indirect methods, it was reported to make chiral derivatization of carvedilol $^{2-6}$ by employing various reagents for analyzing of carvedilol by using

Correspondence to: Mohammad A. Rashid

E-mail: r.pchem@yahoo.com

Tel.: +88-02-9661900-73, Extn.- 8137. Fax: +88-02-9667222

Dhaka Univ. J. Pharm. Sci. 18(1): 61-68, 2019 (June) DOI: https://doi.org/10.3329/dujps.v18i1.41432
RP-HPLC with UV or fluorescence detector, or liquid chromatography-tandem mass spectrometry (LCMS/MS). ${ }^{7}$ In direct methods chiral stationary phase columns and/or mobile phases containing chiral additives are used. ${ }^{8-10} \mathrm{~A}$ chiral selector agent named as hydroxypropyl-beta-cyclodextrin has also been used in capillary electrophoresis for the enantioselective analysis of carvedilol in serum. ${ }^{11,12}$ Now a days, direct chiral separations are being carried out by using chiral stationary phases (CSPs). ${ }^{13}$ Separation of enatiomeric compounds by HPLC is more versatile than GC because GC can separate volatile compounds. However, HPLC with appropriate detection devices can provide fast and accurately the mass and optical rotation of enantiomers as well as quantify them by chiral separation. ${ }^{14,15}$

In this study, separation of carvedilol enantiomers was accomplished by a new 
commercial CSP based upon cellulose tris-(3,5dichlorophenylcarbamate) polymer immobilized on silica. Cellulose and amylose derived chiral stationary phase in the chiral columns are extensively applicable to separate enantiomers with good capability. ${ }^{16-22}$ The objective of the present research work was to develop a rapid, simple and reproducible direct HPLC method for the analysis of enantiomeric compounds of carvedilol.

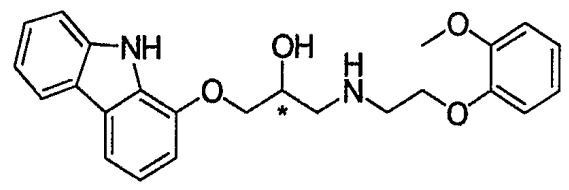

\section{Carvedilol}

Figure 1. Structure of RS carvedilol (* indicates chiral centre).

\section{MATERIALS AND METHODS}

Materials. The standard of carvedilol (>98\%) was a kind gift from Incepta Pharmaceuticals Ltd., Dhaka, Bangladesh. S-carvedilol, HPLC grade hexane, isopropyl alcohol, diethyl amine and acetic acid were purchased from Sigma-Aldrich, Germany. Before analysis, all the solutions and solvents were filtered through $0.45 \mu \mathrm{m}$ membrane filter tips.

Instruments and chromatographic conditions. HPLC was performed on Prominence HPLC (SIL 20 series, Shimadzu, Japan). The instrument was equipped with an auto sampler (Model SIL-20 AC), dual pumps (Model $20 \mathrm{AD}$ ), column oven (Model CTO-20A), vacuum degasser (Model DGU-20A), UV-visible detector (Model SPD-20A). Chromatographic separation was carried out on Chiralpak IC column (4.6 x $250 \mathrm{~mm}$, Chiral Technologies, Daicel group, Tokyo, Japan). The elution was performed with polar mobile phase of hexane: isopropyl alcohol: diethyl amine: acetic acid (40: 60: 0.7: $0.3, \mathrm{v} / \mathrm{v}$ ) at a flow rate of $1.0 \mathrm{~mL} / \mathrm{min}$ and detection was performed at $220 \mathrm{~nm}$.

Standard solutions. Stock standard solutions of concentration of $200 \mu \mathrm{g} / \mathrm{ml}$ of carvedilol were prepared by dissolving $20 \mathrm{mg}$ powder in the mixture of hexane and isopropanol (1:1 v/v) and by adjusting the final volume to $100 \mathrm{ml}$ in a $100 \mathrm{ml}$ volumetric flask. Further dilutions of the stock solutions of carvedilol with appropriate volumes of diluent were carried out to obtain solutions of concentrations of 30 , 60, 80, 100, and $130 \mu \mathrm{g} / \mathrm{ml}$. S-carvedilol standard solution was also prepared and analyzed to confirm the enantiomers of carvedilol.

Sample solutions of carvedilol. Twenty tablets were collected from each 5 companies. Powdersamples equivalent to $5 \mathrm{mg}$ of each brand were transferred to a $50 \mathrm{ml}$ volumetric flask. The content was dissolved with suitable volume of diluents followed by adjusting the final volume up to the mark with diluents. After preparation the samples were analyzed immediately.

\section{Method validation}

Specificity of the method was done by analyzing standard compounds to observe any potential interference. System suitability tests were performed to check the resolution and reproducibility of the chromatographic method. The calibration curves were obtained by plotting the peak area of each enantiomer against the respective concentration and the linearity was evaluated by calculating the regression coefficient values of the curves. The stability of the standard and sample solutions was also checked under normal conditions, normal storage conditions, and sometimes in the special instrument conditions. Accuracy, precisions (intraday and inter-day), LOD and LOQ of the method were carried out according to USP and ICH guidelines. ${ }^{23}$

Robustness of the new method was also checked by changing the chromatographic parameters, like flow rate and wavelength.

Stability test. To study the measuring ability of active ingredient and its degradation products by the new method, the drug was exposed to heat, light, acid, base, and oxidizing agents followed by analysis using the method. The stability tests were carried out under stress conditions including acid hydrolysis $(0.1$ $\mathrm{N} \mathrm{HCl}$ at $\left.60^{\circ} \mathrm{C}\right)$, basic hydrolysis $(0.1 \mathrm{~N} \mathrm{NaOH}$ at $\left.60^{\circ} \mathrm{C}\right)$, peroxide degradation $\left(3 \% \quad \mathrm{H}_{2} \mathrm{O}_{2}\right.$ at $\left.60^{\circ} \mathrm{C}\right)$, thermal degradation $\left(60^{\circ} \mathrm{C}\right)$ and photolysis (at 220 $\mathrm{nm})$ for consecutive five days $\left(1^{\text {st }}, 3^{\text {rd }}\right.$ and $5^{\text {th }}$ days). The drug solutions with concentration of $50 \mu \mathrm{g} / \mathrm{mL}$ 
were prepared in methanol for acid, basic and peroxide, where as samples were prepared with diluent at a concentration of $50 \mu \mathrm{g} / \mathrm{ml}$ for thermal and photolysis degradations. All the resultant solutions were analyzed thrice by the new developed method.

\section{RESULTS AND DISCUSSION}

Method development. In order to analysis of carvedilol enantiomers by a fast and easy chiral HPLC technique we tried to develop a new method using a large number of polar and non-polar solvent mixtures as mobile phase which is shown in table 1 .
Ultimately a suitable chromatographic conditions was achieved with chiralpak IC and $n$-hexane: isopropylalcohol: diethylamine: acetic acid (40: 60: 0.7: $0.3, \mathrm{v} / \mathrm{v})$ as mobile phase due to good resolution with symmetrical peak shape and acceptable theoretical plates number.

Comparison of the present work. The newly developed and validated method was found to be better than previously reported methods for analyzing enantioresolution of carvedilol which is shown in table 2. It clearly established the novelty and superiority of the new method in terms of resolution.

Table 1. Trial methods for carvedilol on chiral chromatography.

\begin{tabular}{|c|c|c|c|c|}
\hline $\begin{array}{l}\text { Polar mobile phase } \\
\text { Buffer:organic phase/others }\end{array}$ & Retention time & $\begin{array}{l}\text { Theoretical plates } \\
\qquad(\geq 2000)\end{array}$ & $\begin{array}{l}\text { Tailing factor } \\
\qquad(\leq 2)\end{array}$ & $\begin{array}{l}\text { Resolution } \\
\quad(\geq 2)\end{array}$ \\
\hline Methanol- $\mathrm{H}_{2} \mathrm{O}(50: 50)$ & No peak observed & NA & NA & NA \\
\hline Ammonium acetate-Methanol (20:80) & No peak observed & NA & NA & NA \\
\hline Ammonium acetate-Methanol (60:40) & No peak observed & NA & NA & NA \\
\hline $\begin{array}{l}\text { Ammonium dihydrogen phosphate- } \\
\text { Methanol (30:70) }\end{array}$ & No peak observed & NA & NA & NA \\
\hline Non-polar mobile phase & Retention time & $\begin{array}{l}\text { Theoretical plates } \\
\qquad(\geq 2000)\end{array}$ & $\begin{array}{c}\text { Tailing factor } \\
(\leq 2)\end{array}$ & Resolution $(\geq 2)$ \\
\hline Hexane-Isopropylalcohol (50: 50) & One peak observed & NA & NA & NA \\
\hline $\begin{array}{l}\text { Hexane-Isopropylalcohol } \\
(90: 10)\end{array}$ & One peak observed & NA & NA & NA \\
\hline $\begin{array}{l}\text { Hexane-Isopropylalcohol-Diethylamine } \\
(70: 30: 0.1)\end{array}$ & Two peaks observed & NA & $\begin{array}{l}3.6 \\
3.9\end{array}$ & NA \\
\hline $\begin{array}{l}\text { Hexane-Isopropylalcohol-Acetic acid } \\
(40: 50: 0.1)\end{array}$ & Two peaks observed & $\begin{array}{c}1010 \\
998 \\
\end{array}$ & $\begin{array}{l}1.5 \\
1.3\end{array}$ & 1.07 \\
\hline
\end{tabular}

Table 2. Comparison of HPLC resolution of carvedilol using different columns.

\begin{tabular}{llcc}
\hline Chiral column/ selector & Mobile phase & Resolution (Rs) & Reference \\
\hline Lux cellulose- 4 & Isopropanol-n-hexane (60:40) & 1.9 & E. Swetha et al. (2015) \\
Chiral selector HP- $\beta$-CD & 50 mM phosphate buffer (pH 4.0) & 2.34 & N.T. Phuong et al. (2004) \\
Chiral selector- $\beta-C D$ & 25 mM phosphoric acid (pH 2.5) & 2.5 & Gabriel Hancu et al. (2015) \\
Chiralpak-IC & $\begin{array}{l}\text { n-hexane: isopropyl alcohol- } \\
\text { diethylamine-acetic acid (40:60:0.7:0.3) }\end{array}$ & 7.9 & Present work \\
\hline
\end{tabular}

Finally, this present method has been extensively validated according to the following parameters.

Validation of the proposed method. ${ }^{23}$

Linearity and range. Linearity of the method was achieved by triplicate injection of five concentrations of each two enantiomers of carvedilol in concentration range of $30-130 \mu \mathrm{g} / \mathrm{ml}$. To obtain the calibration curves corresponding peak areas were plotted against concentrations (figure 2, table 3).

Precision. Intraday and inter-day precisions were studied by injecting six replicates of one 
concentration on same day and on three different days, respectively. Results are shown in table 3 .
Accuracy. Accuracy was determined by successive analysis $(n=3)$ of standard solutions with spiking of the drug and the results are shown in table 4 .

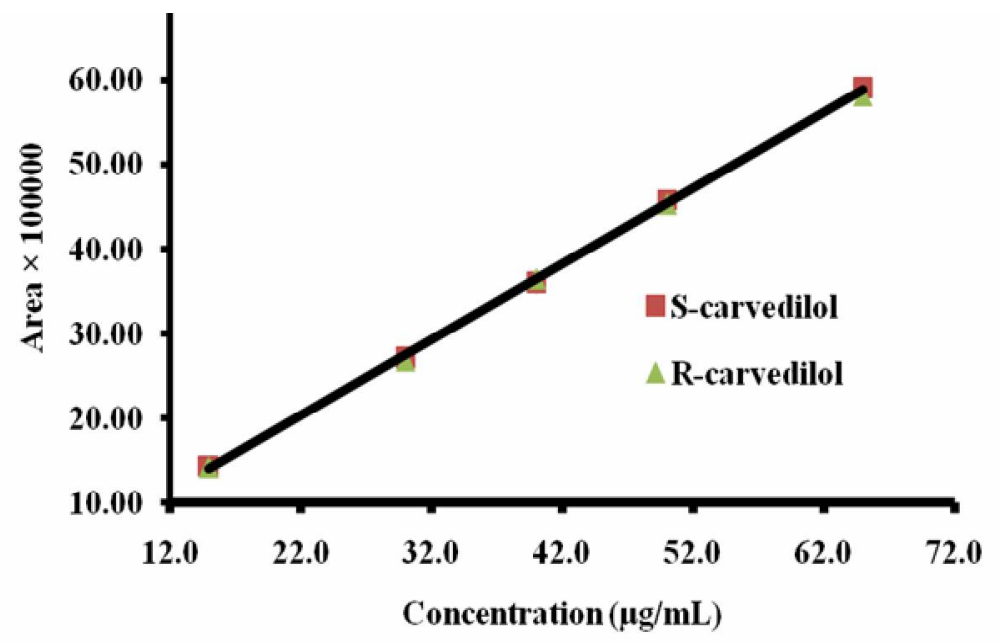

Figure 2. Linearity curve for $(S)$ - and $(R)$-carvedilol.

Table 3. Results of method validation parameters.

\begin{tabular}{lcc}
\hline Parameters & $S$-carvedilol & $R$-carvedilol \\
\hline Linear equation & $\mathrm{y}=89799 \mathrm{x}+49478$ & $\mathrm{y}=88273 \mathrm{x}+86175$ \\
Coefficient of determination $(\mathrm{r} 2>0.995)$ & 0.999 & 0.999 \\
Linearity range & $30-130 \mu \mathrm{g} / \mathrm{mL}$ & $30-130 \mu \mathrm{g} / \mathrm{mL}$ \\
Precision (intra-day, $\mathrm{n}=6)(\% \mathrm{RSD} \leq 2)$ & $0.0 .02 \%$ & $0.07 \%$ \\
Precision (inter-day, $\mathrm{n}=6)(\% \mathrm{RSD} \leq 2)$ & $0.03 \%$ & $0.07 \%$ \\
\hline
\end{tabular}

$\mathrm{n}=$ number of determinations

Table 4. Results of accuracy.

\begin{tabular}{lll}
\hline Accuracy $(\mathrm{n}=3)($ avg. \% recovery) & $S$-carvedilol & $R$-carvedilol \\
Standard + spike $(\mu \mathrm{g} / \mathrm{ml})$ & & \\
\hline$(50+20)$ & $99.59 \%$ & $98.42 \%$ \\
$(60+20)$ & $100.83 \%$ & $100.18 \%$ \\
$(80+20)$ & $99.79 \%$ & $99.25 \%$ \\
$\mathrm{LOD}(\mu \mathrm{g} / \mathrm{ml})$ & 1.67 & 1.78 \\
$\mathrm{LOQ}(\mu \mathrm{g} / \mathrm{ml})$ & 5.06 & 5.41 \\
\hline
\end{tabular}

$\mathrm{n}=$ number of determinations

Limit of detection (LOD) and limit of quantification (LOQ). LOD and LOQ were obtained from the calibration curve by using the following equations: $\mathrm{LOD}=3.3 \mathrm{SD} / \mathrm{S}$ and $\mathrm{LOQ}=10 \mathrm{SD} / \mathrm{S}$, where, $\mathrm{SD}$ is residual standard deviation of regression line and $\mathrm{S}$ is the slope of the line. The results are shown in table 4.

Specificity. The specificity of the method for carvedilol and S-carvedilol was achieved without any interference as shown in figure 3. 


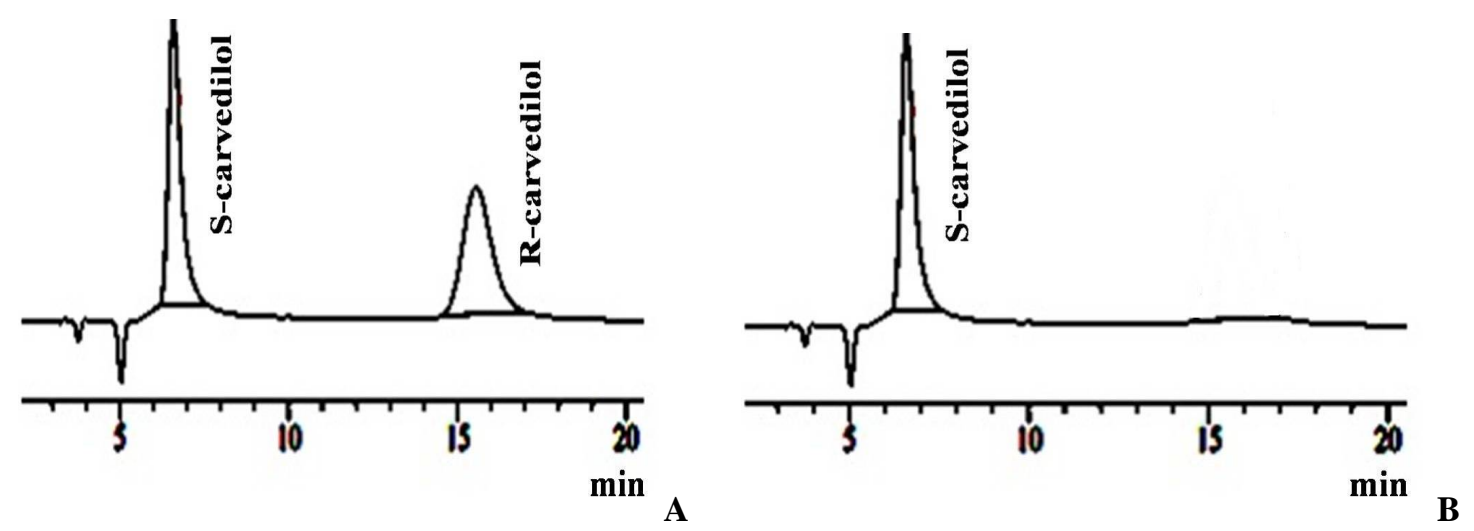

Figure 3. HPLC chromatograms of racemic carvedilol (A) and $S$-carvedilol (B).

Table 5, System suitability testing.

\begin{tabular}{lcc}
\hline Parameters & $S$-carvedilol & $R$-carvedilol \\
\hline Theoretical plates $(\geq 2000)(\mathrm{n}=5)$ & 2198 & 2211 \\
Tailing factor $(\leq 2)(\mathrm{n}=5)$ & 1.23 & 1.62 \\
Relative retention $\left(\mathrm{k}_{\mathrm{S}}\right.$ and $\left.\mathrm{k}_{\mathrm{R}}\right)(\mathrm{n}=5)$ & 1.1 & \\
Selectivity $(\alpha)(\mathrm{n}=5)$ & 3.26 & \\
Resolution $(\geq 2)(\mathrm{n}=5)$ & 7.9 & \\
\hline
\end{tabular}

$\mathrm{n}=$ number of determinations

System suitability. Retention factor (k), enantioseparation factor $(\alpha)$, and resolution $(R)$ for system suitability were determined using the following equations: $\mathrm{k}=\left(\mathrm{t}-\mathrm{t}_{0}\right) / \mathrm{t}_{0}$, where $\mathrm{t}$ and $\mathrm{t}_{0}$ are the retention times of carvedilol and unretained solutes, respectively; $\alpha=\mathrm{k}_{\mathrm{R}} / \mathrm{k}_{\mathrm{S}}$, where $\mathrm{k}_{\mathrm{S}}$ and $\mathrm{k}_{\mathrm{R}}$ are the retention factors of $(S)$ - and $(R)$-enantiomer of carvedilol, respectively; $\mathrm{R}=2\left(\mathrm{t}_{\mathrm{R}}-\mathrm{t}_{\mathrm{S}}\right) /\left(\mathrm{w}_{\mathrm{R}}+\mathrm{w}_{\mathrm{S}}\right)$, where $\mathrm{t}_{\mathrm{S}}$ and $\mathrm{t}_{\mathrm{R}}$ are retention times of the $(S)$ - and $(R)$ enantiomers, respectively, and $\mathrm{w}_{S}$ and $\mathrm{w}_{\mathrm{R}}$ are the baseline peak widths of the two enantiomers. The parameters of system suitability tests are given in table 5.

Solution stability. Table 6 shows the results of solution stability tests which were obtained after keeping pure drug solutions $(60 \mu \mathrm{g} / \mathrm{ml})$ in tightly capped volumetric flask at room temperature $\left(25^{\circ} \mathrm{C}\right)$ and at $4{ }^{\circ} \mathrm{C}$ for 3 days.
Robustness of the method. The robustness for the developed method, flow rate and wavelength were changed a minor range i.e. $(1.0 \pm 0.2 \mathrm{ml} / \mathrm{min}),(220 \pm$ $2 \mathrm{~nm})$, respectively. The results of the robustness wer expressed in \% RSD and are shown in table 7. All peaks of the carvedilol were remaining unchanged.

Stability test. The drug was exposed to acid, alkali, oxidative, photolysis and thermal stress conditions for five days and on $1^{\text {st }}, 3^{\text {rd }}$, and $5^{\text {th }}$ days, aliquot of the samples were analyzed to check the degradation. In photolysis, carvedilol was completely degraded and in other conditions it remained almost stable. The stability tests results are shown in table 8 .

Application of the method. The new method was used to analyze carvedilol in pharmaceutical preparation and also to determine the enantiomeric purity of the samples. Results of enantiomeric purity of five commercial samples are shown in figure 4 and table 8 . 
Table 6. Results of the solution stability tests.

\begin{tabular}{|c|c|c|c|c|}
\hline Day & At $25^{\circ} \mathrm{C}$ & & At $4^{\circ} \mathrm{C}$ & \\
\hline & $\begin{array}{l}S \text {-carvedilol } \\
(\mathrm{n}=3)(\% \text { RSD })\end{array}$ & $\begin{array}{l}R \text {-carvedilol } \\
(\mathrm{n}=3)(\% \mathrm{RSD})\end{array}$ & $\begin{array}{l}S \text {-carvedilol } \\
(\mathrm{n}=3)(\% \mathrm{RSD})\end{array}$ & $\begin{array}{l}R \text {-carvedilol } \\
(\mathrm{n}=3)(\% \mathrm{RSD})\end{array}$ \\
\hline Day 1 & $0.00 \%$ & $0.03 \%$ & $0.01 \%$ & $0.01 \%$ \\
\hline Day 2 & $0.01 \%$ & $0.02 \%$ & $0.03 \%$ & $0.01 \%$ \\
\hline Day 3 & $0.02 \%$ & $0.01 \%$ & $0.02 \%$ & $0.00 \%$ \\
\hline Avg. & $0.01 \%$ & $0.02 \%$ & $0.02 \%$ & $0.01 \%$ \\
\hline
\end{tabular}

$\mathrm{n}=$ number of determinations

Table 7. Results of the robustness studies.

\begin{tabular}{lllll}
\hline $\begin{array}{l}\text { Change in flow rate } \\
(\mathrm{mL} / \mathrm{min})\end{array}$ & $\begin{array}{l}\text { Average Rt of S-carvedilol } \\
\text { SD }\end{array}$ & $\begin{array}{l}\text { Average Rt of R-carvedilol } \\
\pm \mathrm{SD}\end{array}$ & $\begin{array}{l}\text { \% RSD of S- } \\
\text { carvedilol }\end{array}$ & $\begin{array}{l}\text { \% RSD of R- } \\
\text { carvedilol }\end{array}$ \\
\hline 0.8 & $19.78 \pm 0.01$ & $8.31 \pm 0.01$ & $0.03 \%$ & $0.07 \%$ \\
1.0 & $16.77 \pm 0.01$ & $6.63 \pm 0.01$ & $0.03 \%$ & $0.09 \%$ \\
1.2 & $13.32 \pm 0.01$ & $5.56 \pm 0.01$ & $0.04 \%$ & $0.10 \%$ \\
\hline $\begin{array}{l}\text { Change in wavelength } \\
(\mathrm{nm})\end{array}$ & $\begin{array}{l}\text { Average area of S-carvedilol } \\
\pm \text { SD }\end{array}$ & $\begin{array}{l}\text { Average area of R- } \\
\text { carvedilol } \pm \text { SD }\end{array}$ & $\begin{array}{l}\% \text { RSD of S- } \\
\text { carvedilol }\end{array}$ & $\begin{array}{l}\% \text { RSD of R- } \\
\text { carvedilol }\end{array}$ \\
\hline 218 & $4432733 \pm 5420.59$ & $4227849 \pm 5161.53$ & $0.11 \%$ & $0.12 \%$ \\
220 & $5002292 \pm 1042.76$ & $4851746 \pm 1147.56$ & $0.11 \%$ & $0.02 \%$ \\
222 & $4847542 \pm 1655.06$ & $4636964 \pm 5792.36$ & $0.24 \%$ & $0.12 \%$ \\
\hline
\end{tabular}

$R_{t}=$ retention time, $n=3$; where, $n=$ number of determinations

Table 8. Results of stress degradation studies $(n=3)$.

\begin{tabular}{|c|c|c|c|c|c|c|}
\hline \multirow[t]{2}{*}{ Degradation conditions } & \multicolumn{2}{|c|}{ Day 1} & \multicolumn{2}{|c|}{ Day 3} & \multicolumn{2}{|c|}{ Day 5} \\
\hline & $S$-carvedilol & $R$-carvedilol & $S$-carvedilol & $R$-carvedilol & $S$-carvedilol & $R$-carvedilol \\
\hline $\begin{array}{l}\text { Methanolic } 0.1 \mathrm{~N} \mathrm{HCl} \\
\left(\text { at } 60^{\circ} \mathrm{C}\right)\end{array}$ & $0.04 \%$ & $0.03 \%$ & $0.05 \%$ & $0.04 \%$ & $0.05 \%$ & $0.04 \%$ \\
\hline $\begin{array}{l}\text { Methanolic } 0.1 \mathrm{~N} \\
\mathrm{NaOH}\left(\text { at } 60{ }^{\circ} \mathrm{C}\right)\end{array}$ & $0.01 \%$ & $0.10 \%$ & $0.02 \%$ & $0.01 \%$ & $0.02 \%$ & $0.01 \%$ \\
\hline $\begin{array}{l}\text { Methanolic 3\% } \mathrm{H}_{2} \mathrm{O}_{2} \text { (at } \\
60{ }^{\circ} \mathrm{C} \text { ) }\end{array}$ & $4.34 \%$ & $2.72 \%$ & $4.36 \%$ & $2.94 \%$ & $4.36 \%$ & $3.33 \%$ \\
\hline Thermal $\left(\right.$ at $\left.60{ }^{\circ} \mathrm{C}\right)$ & $0.00 \%$ & $0.01 \%$ & $0.00 \%$ & $0.07 \%$ & $0.00 \%$ & $0.08 \%$ \\
\hline Photolysis (at $254 \mathrm{~nm}$ ) & $\mathrm{cd}$ & $\mathrm{cd}$ & $\mathrm{cd}$ & $\mathrm{cd}$ & $\mathrm{cd}$ & $\mathrm{cd}$ \\
\hline
\end{tabular}

$\mathrm{cd}=$ completely degraded

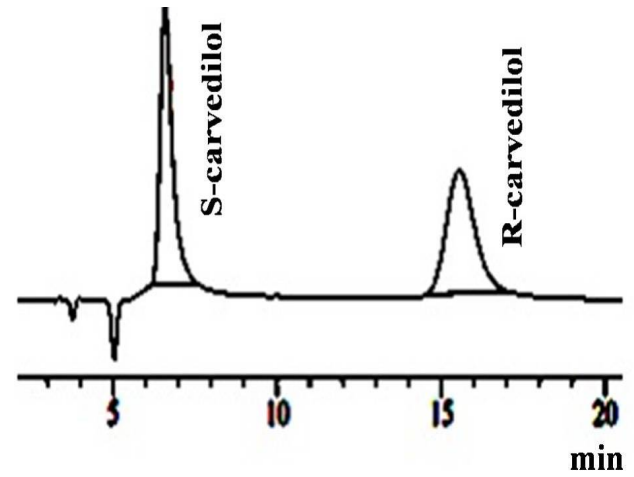

Figure 4. HPLC chromatogram of one commercial sample. 
Table 8. Percent purity of racemic carvedilol in commercial samples.

\begin{tabular}{lcccc}
\hline Identity of samples & $\begin{array}{c}\text { \% Content of } S- \\
\text { carvedilol }\end{array}$ & $\begin{array}{c}\text { \% Impurity of } S- \\
\text { carvedilol }\end{array}$ & $\begin{array}{c}\text { \% Content of } R \text { - } \\
\text { carvedilol }\end{array}$ & \% Impurity of $R$-isomer \\
\hline Sample A & $49.84 \%$ & $0.16 \%$ & $50.15 \%$ & $-0.15 \%$ \\
Sample B & $49.45 \%$ & $0.55 \%$ & $50.54 \%$ & $-0.54 \%$ \\
Sample C & $49.57 \%$ & $0.43 \%$ & $50.42 \%$ & $-0.42 \%$ \\
Sample D & $48.77 \%$ & $1.23 \%$ & $51.23 \%$ & $-1.23 \%$ \\
Sample E & $49.86 \%$ & $0.14 \%$ & $50.13 \%$ & $-0.13 \%$ \\
\hline
\end{tabular}

\section{CONCLUSION}

A sensitive, simple, and accurate method for enantioseparation of carvedilol enantiomers was developed by chiralpak IC column. The method provided good enantioseparation factor $(\alpha=3.26)$ and resolution $(\mathrm{R}=7.9)$ with the mobile phase of hexane-isopropyl alcohol-diethyl amine-acetic acid (40: 60: 0.7: 0.3, v/v).

By this method $(S)$ - and $(R)$ - carvedilol were identified rapidly by a single analysis (approximately within $17 \mathrm{~min}$ ). This method was also validated properly and it was found that the method was simple, fast, accurate, repeatable and precise. Therefore, the method can be used for the routine analysis of carvedilol enantiomers in pharmaceutical formulations.

\section{ACKNOWLEDGEMENTS}

The authors extended their thanks and gratitude to Incepta Pharmaceuticals Ltd., Savar, Bangladesh for providing pure drug (carvedilol).

\section{Conflict of Interests}

The authors declare that there is no conflict of interests regarding the publication of this paper.

\section{REFERENCES}

1. Bartsch, W., Spone, G., Strein, K., Müller-Beckmann, B., Kling, L., Böhm, E., Martin, U. and Borbe, H.O. 1990. Pharmacological characteristics of the stereoisomers of carvedilol. Eur. J.Clin. Pharmacol. 38,104-107.

2. Bhushan, R. and Dixit, S. 2012. Enantioresolution of Five $\beta$-blockers by reversed-phase high performance liquid chromatography using fifteen chiral derivatizing reagents having amino acids or their amides as chiral auxilia- ries on a cyanuric chloride platform. Biomed. Chrom. 26, 239-246.
3. Yang, E., Wang, S., Kratz, J. and Cyronak, M.J. 2004. Stereoselective analysis of carvedilol in human plasma using HPLC/MS/MS after chiral derivatization. J. Pharm. Biomed. Anal. 36, 609-615.

4. Zakrzewski-Jakubiaka, M., de Denusb, S., Leblancc, M.-H., Whiteb, M. and Turgeon, J. 2010. Enantioselective quantification of carvedilol in human plasma by HPLC in heavily medicated heart failure patients. J. Pharm. Biomed. Anal. 52, 636-641.

5. Spahn, H., Henke, W., Langguth, P., Schloos, J. and Mutschler, E. 1990. Measurement of carvedilol enantiomers in human plasma and urine using S-naproxen chloride for chiral derivatization. Arch. Der. Pharm. 323, 465-469.

6. Peccinini, R.G., Ximenes, V.F., Cesarino, E.J. and Lanchote, V.L. 2008. Stereoselective analysis of carvedilol in human plasma and urine using HPLC after chiral derivatization. Biopharm. Drug Dispos. 29, 280-288.

7. Wang, S., Cyronak, M. and Yang, E. 2007. Does a stable isotopically labeled internal standard always correct analyte response? A matrix effect study on a LC/MS/MS method for the determination of carvedilol enantiomers in human plasma. J. Pharm. Biomed. Anal. 43, 701-707.

8. Clohs, L. and McErlane, K.M. 2003. Comparison between capillary electrophoresis and high performance liquid chromatography for the stereoselective analysis of carvedilol in serum. J. Pharm. Biomed. Anal. 31, 407-412.

9. Saito, M., Kawana, J., Ohno, T., Kaneko, M., Mihara, K., Hanada, K., et al. 2006. Enantioselective and highly sensitive determination of carvedilol in human plasma and whole blood after administration of the racemate using normal-phase high-performance liquid chromatography. $J$. Chromatogr. B. 843, 73-77.

10. Medvedovici, A., Albu, F., Georgita, C., Sora, D.I., Galaon, T., Udrescu, S., et al. 2007. Achiral-chiral LC/LC-FLD coupling for determination of carvedilol in plasma samples for bioequivalence purposes. J. Chromatogr. B. 850, 327335 .

11. Clohs, L. and McErlane, K.M. 2001. Development of a capillary electrophoresis assay for the determination of carvedilol enantiomers in serum using cyclodextrins. $J$. Pharm. Biomed. Anal.24, 545-554. 
12. Behn, F., Michels, S., Laer, S. and Blaschke, G. 2001. Separation of carvedilol enantiomers in very small volumes of human plasma by capillary electrophoresis with laserinduced fluorescence. J. Chromatogr. B. 755, 111-117.

13. Koppenhoefer, B., Nothdurft, A., Pierrot-Sanders, J., Piras, P., Popescu, C., Roussel, C., Stiebler, M. and Trettin, U. 1993. CHIRBASE, a graphical molecular database on the separation of enantiomers by liquid-, supercritical fluid-, and gas chromatography. Chirality. 5, 213-219.

14. W. Boehme, G. Wagner and U. Oehme, 1982. spectrophotometric and polarimetric detectors in liquid. chromatography for the determination of enantiomer ratios in. complex mixtures. Anal. Chem. 54, 709-711.

15. Purdie, N. and Swallows, K.A.1989. Analytical applications of polarimetry, optical rotatory dispersion, and circular dichroism. Anal. Chem., 61, 77A-89A.

16. Yang, G., Vazquez, P.P., Frenich, A. G., Vidal, J.L.M. and Aboul-Enein, H.Y. 2004. Chiral separation of several pyrethroids on polysaccharide-based chiral stationary phases under normal and reversed phase modes. J. Liq. Chromatogr. Rel. Technol. 27, 1507-1521.

17. Cirilli, R., Ferretti, R., Gallinella, B., De Santis, E., Zanitti, L. and Torre, F.L. 2008. High-performance liquid chromatography enantioseparation of proton pump inhibitors using the immobilized amylose-based Chiralpak IA chiral stationary phase in normal-phase, polar organic and reversed-phase conditions. J. chromatogr. A. 1177, 105-113.
18. Raghuram, P., Soma Raju, I.V. and Sriamulu, J. 2009. A rapid stability indicating lc method for efavirenz enantiomer using RRLC. Trade Sci. Inc. 8, 145-152.

19. Sharma, S.D. and Singh, G. 2012. Enantioseparation of nadifloxacin by high performance liquid chromatography. Adv. Anal. Chem. 2, 25-31.

20. Ozkirimlia, S., Aboul-Eneinb, H.Y. and Cesura, N. 2011. Enantioselective quantification of doxylamine in human plasma by HPLC. J. Liq. Chromatogr. Relat. Technol. 34, 671-678.

21. Ali, I., Saleem, K., Hussain, I., Gaitonde, V.D. and Aboul Enein, H.Y. 2009. Polysaccharides chiral stationary phases in liquid chromatography. J. Liq. Chromatogr. Relat. Technol. 38, 97-147.

22. Maier, N.M., Franco, P. and Linder, W. 2001. Separation of enantiomers: needs challenges, perspectives. J. Chromatogr. A. 906, 3-33.

23. International Conference on Harmonisation (ICH), validation of analytical procedures: Text and Methodology Q2(R1) in November 2005. 